\title{
Effect of Fermentation Time and Starbio Bioactivator Type and Local Microorganism (MOL) "Ginta" on The Nutritional Quality of Cassava Tuber Skin (Manihot Utilisima)
}

\author{
Bahria Nasution, Hasnudi, Nurzainah Ginting, Yunilas, Hamdan. \\ Animal Production Program Study, Faculty of Agriculture, University of North \\ Sumatera, Medan 20155, Indonesia \\ E-mail: bahrianasution1703@gmail.com
}

\begin{abstract}
BAHRIA NASUTION, 2018. "The Influence of Old Fermentation And Types Of Starbio Bioactivators And Local Microorganisms (MOL)" Ginta "Against Quality Nutritional Skin Cassava Bulbs (Manihot Utilisima). Guided by HASNUDI and NURZAINAH GINTING. The aim of this research is to know the nutrient content of cassava tuber skin waste (Manihot utilisima) fermented with starbio bioactivator type and local microorganism (MOL) "ginta". This research was conducted at Nutrition Research Lab for Nutritional Research on Goat Cut Sei Putih, from July to August 2017. The design used in this study was a complete randomized design (RAL) patterned $3 \times 3$ pattern with 3 replications. Factor I is fermentation starbio, fermentation of local microorganism (ginta), fermentation starbio + local microorganism (MOL) "ginta". Factor II is the fermentation length of 6.10 and 14 days. The parameters studied were water content, crude protein, crude fiber, ash content, crude fat, BETN.

The result of bioactivator type research gave a very significant $(\mathrm{P}<0,01)$ to water content, crude protein, crude fiber and BETN of fermented cassava peel. The duration of fermentation had a very significant effect $(\mathrm{P}<0.01)$ on crude protein and lower ash, coarse, and coarse fat. The conclusion of fermentation using starbio can increase the crude protein, BETN and lower crude fiber, and ash content.
\end{abstract}

\section{Introduction}

Keywords : Cassava peel, fermentation, starbio, Bioactivator,"Ginta" Local Migroorganisms.

In a cultivation business, feed is one of the determinants of the success of a livestock business in addition to two components related to breeding and management. Quality feed will provide quality results as well. Feed is one of the components with the biggest expenditure. The high price of feed related to raw materials becomes the biggest problem for farmers in its supply for the production and productivity of livestock. Cassava peel is a huge amount of organic waste, because all this time the community only takes the crop in the form of sweet potatoes, while the skin is left to rot until it is decomposed and decomposed by decomposing bacteria. Cassava skin is also one of the waste that its existence is less desirable by the community in its processing into alternative feed for livestock, especially ruminants. The higher the level of community's preference for cassava, the higher the waste will be produced and can pollute the environment if not immediately utilized.

Utilization of existing agricultural wastes such as cassava as an alternative feed for livestock certainly provides a positive value for profit. For this reason, the need to find and process existing waste with good quality and quantity, low cost and continuity to be used as animal feed. In general, agricultural byproducts have several properties such as low nutritional value, especially protein and digestibility, easily rot, are bulky, so transportation costs are expensive because they require more space for certain units of weight, high humidity, making it difficult to store and look less pleasant.

\section{Materials and Research Methods}


The research was conducted at the Nutrition Feed Laboratoty of the Sei Putih Goat Research Station for 8 weeks from July to Agust 2017. The materials used are starbio and local microorganism (MOL) "Ginta", water to wash the skin of cassava tuber, label name to give mark on fermentation plastic, white plastic size $1 \mathrm{~kg}$ as place of fermentation. The fermented feed ingredients consist of cassava tuber skin. The chemicals used for the analysis are: Organic solvent (Hexane), H2SO4 1,25\%, NaOH 1,25\%, Ethanol, Diethyl Esther, Aquadest, H2O2, Penolphtalein, Borax Acid (H3BO3) 3\%, Indicator mix, HCl 0 , $01 \mathrm{~N}$ and Selenium. The tools used are electric scales, buckets, machetes, tarps, drums as a place to cassava tuber skin fermentation, grider The tools used for analysis are: $1050 \mathrm{C}$ oven, desiccator, electric scales, porcelain dishes, furnaces, soxhlet extraction tools, boiling, soxhlet tube, vacuum pump, sucker funnel, Glass beaker, clamping pliers, Kjehdahl extraction tool, titration tool, erlenmeyer, test tube, measuring cup, drop pipette and stationery.

The research method used was Completely Randomized Design (CRD) with factorial $3 \times 3$ and 3 experimental replications. So that yielded 9 treatment combination and 3 replication. The first factor is the type of bioctivator with 3 treatments, namely:

F1: Fermentation with Starbio

F2: Fermentation With Local Microorganisms "Ginta"

F3: Fermentation With Starbio + Local Microorganisms "Ginta"

The second factor is the length of fermentation with 3 treatments, namely:

H1: 6 days

H2: 10 days

H3: 14 days

Randomized treatment treatment with 3 replications was as follows :

\begin{tabular}{|l|l|l|l|l|l|l|l|l|}
\hline $\mathrm{F}_{1} \mathrm{H}_{2} \mathrm{U}_{2}$ & $\mathrm{~F}_{2} \mathrm{H}_{1} \mathrm{U}_{1}$ & $\mathrm{~F}_{2} \mathrm{H}_{2} \mathrm{U}_{2}$ & $\mathrm{~F}_{1} \mathrm{H}_{3} \mathrm{U}_{3}$ & $\mathrm{~F}_{3} \mathrm{H}_{1} \mathrm{U}_{2}$ & $\mathrm{~F}_{3} \mathrm{H}_{2} \mathrm{U}_{1}$ & $\mathrm{~F}_{1} \mathrm{H}_{1} \mathrm{U}_{1}$ & $\mathrm{~F}_{2} \mathrm{H}_{1} \mathrm{U}_{3}$ & $\mathrm{~F}_{2} \mathrm{H}_{3} \mathrm{U}_{2}$ \\
\hline $\mathrm{F}_{1} \mathrm{H}_{1} \mathrm{U}_{2}$ & $\mathrm{~F}_{2} \mathrm{H}_{2} \mathrm{U}_{1}$ & $\mathrm{~F}_{2} \mathrm{H}_{3} \mathrm{U}_{3}$ & $\mathrm{~F}_{3} \mathrm{H}_{1} \mathrm{U}_{3}$ & $\mathrm{~F}_{3} \mathrm{H}_{2} \mathrm{U}_{2}$ & $\mathrm{~F}_{1} \mathrm{H}_{1} \mathrm{U}_{3}$ & $\mathrm{~F}_{1} \mathrm{H}_{2} \mathrm{U}_{3}$ & $\mathrm{~F}_{3} \mathrm{H}_{3} \mathrm{U}_{3}$ & $\mathrm{~F}_{3} \mathrm{H}_{2} \mathrm{U}_{3}$ \\
\hline $\mathrm{F}_{3} \mathrm{H}_{3} \mathrm{U}_{2}$ & $\mathrm{~F}_{1} \mathrm{H}_{2} \mathrm{U}_{1}$ & $\mathrm{~F}_{1} \mathrm{H}_{3} \mathrm{U}_{2}$ & $\mathrm{~F}_{2} \mathrm{H}_{3} \mathrm{U}_{1}$ & $\mathrm{~F}_{3} \mathrm{H}_{3} \mathrm{U}_{1}$ & $\mathrm{~F}_{1} \mathrm{H}_{3} \mathrm{U}_{1}$ & $\mathrm{~F}_{2} \mathrm{H}_{1} \mathrm{U}_{2}$ & $\mathrm{~F}_{3} \mathrm{H}_{1} \mathrm{U}_{1}$ & $\mathrm{~F}_{2} \mathrm{H}_{2} \mathrm{U}_{3}$ \\
\hline
\end{tabular}

a.b ( $\mathrm{r}-1)>15$ According to Feeder (1967)

number of factors $x$ number of combinations of treatments $(\mathrm{r}-1)>15$

$3 \times 3(\mathrm{r}-1)>15$

$9 \mathrm{r}-9>15$

$9 \mathrm{r}=15+9$

$24 \mathrm{r}=24=2.6$

9

$\mathrm{r}=3$

Information :

$\mathrm{a}=$ fermentation factor

$\mathrm{b}=$ day factor

$r=$ repeat

\subsection{Research Implementation}

Making Local Microorganisms (MOL) "Ginta" Making of Lokol Microorganism (MOL) "Ginta" using some materials such as water with $90,36 \%$ as substrate solvent and bacteria breeding, sugar as much as $6,02 \%$ substrate, tempe $1,8 \%$ as source of inokulum and substrate, honey $1,2 \%$ as a substrate, $0.12 \%$ yeast tape as inoculum and substrate, and $0.5 \%$ yakult as inoculum and substrate. Everything is put into a gallon of size 19 liters, the hole is covered with a plastic bag size $1 \mathrm{~kg}$ and left for 5 days and every day is 
shaking for about 1 minute with the aim of leveling between microbes and bacteria for the sake of continuity symbiosis mutualism. The purpose of closing with aqua bottle is to get an indication of whether the microorganisms that will be activated to work or not, where the bottle aqua bubbles occur occurs positive reaction of microorganisms in the making stage of MOL "Ginta".

\subsection{Fermentation with starbio}

Cassava tuber skin is washed clean with clean water, then dried in the sun for 4-5 days, After drying the wood tuber skin water content is lost $60 \%$. After the cassava tuber skin is dry then grinder, starbio mixed with a dose of $0.5 \%$ until smooth and then stirred and put into the drum and allowed to stand for the treatment time.

\subsection{Fermentation with MOL "Ginta"}

Skin of cassava tubers that have been washed and dried in ready, then in the grinder to become flour,then mixed with MOL "ginta" $0,5 \%$ to flat.The put in the drum and leave it for treatment.

\subsection{Fermentation of Starbio Interaction with MOL "Ginta"}

Dry cassava bulbs are prepared,the in the grinder until the starch is fermented with starbio,then added with MOL "Ginta" with a dose of $0,5 \%$ and strired until evenly and silenced during the treatment time.

Parameter of Research

1. Dry material

2. Water content

3. Rough protein

4. Coarse fat

\section{Rough fiber}

6. Ash content

7. BETN

\section{Results and Discussion}

\subsection{Dry matter}

Dry matter is one of the results of the distribution of fractions derived from feed ingredients after reducing the water content. Water content is the percentage of water content of a material that can be expressed based on wet weight (wet basis) or dry weight (Immawatitari, 2014).

\begin{tabular}{lllll}
\hline Bioactivator & \multicolumn{2}{l}{ Fermentation Length (days) } & \multicolumn{2}{c}{ Average } \\
& H1 (6) & H2 (10) & H3 (14) & \\
\hline F1 ( Starbio ) & $91,15^{\mathrm{a}}$ & $92,08^{\mathrm{b}}$ & $92,08^{\mathrm{b}}$ & $91,77^{\mathrm{b}}$ \\
F2 ( Ginta ) & $91,09^{\mathrm{a}}$ & $91,15^{\mathrm{a}}$ & $92,14^{\mathrm{b}}$ & $91,46^{\mathrm{a}}$ \\
F3 (Starbio + Ginta) & $91,19^{\mathrm{a}}$ & $92,17^{\mathrm{b}}$ & $91,17^{\mathrm{b}}$ & $91,51^{\mathrm{a}}$ \\
\hline Average & $91,14^{\mathrm{a}}$ & $91,8^{\mathrm{a}}$ & $91,79^{\mathrm{b}}$ & 91,58 \\
\hline
\end{tabular}

The highest value of dry matter is 92.17 in $\mathrm{F} 3 \mathrm{H} 2$ treatment (local microorganism bioactivator "ginta" with 10 days fermentation time) and the lowest is 91.09 in F2H1 treatment (bioactivator of local microorganisms "ginta" with 6 days fermentation time). This is consistent with the statement of Surono et al. (2006) which states that an increase in water content during ensilage causes the dry matter of silage to decrease, causing an increase in dry matter loss. The higher the water produced during the encylase, the more dry material loss will increase. Therefore, an increase in dry matter loss is also influenced by an increase in water content derived from fermentation.

\subsection{Water content}

Water is one of the by-products of the fermentation process which will affect the level of substrate water fermentation products. Increased water content is due to microorganisms starting to utilize carbohydrates which are easily fermented in the substrate as an energy source to grow and develop. 


\begin{tabular}{llrrl}
\hline \multirow{2}{*}{ Bioactivator } & \multicolumn{3}{c}{ Fermentation Length (days) } & \multirow{2}{*}{ Average } \\
\cline { 2 - 3 } & H1 (6) H2 (10) & \multicolumn{1}{c}{$\mathrm{H} 3(14)$} & \\
\hline F1 ( Starbio ) & $8,85^{\mathrm{a}}$ & $7,92^{\mathrm{b}}$ & $7,91^{\mathrm{b}}$ & $8,22^{\mathrm{b}}$ \\
F2 ( Ginta ) & $8,90^{\mathrm{a}}$ & $8,84^{\mathrm{b}}$ & $7,85^{\mathrm{b}}$ & $8,53^{\mathrm{b}}$ \\
F3 (Starbio + Ginta) & $8,80^{\mathrm{a}}$ & $7,82^{\mathrm{b}}$ & $8,81^{\mathrm{a}}$ & $8,47^{\mathrm{a}}$ \\
\hline Average & $8,85^{\mathrm{a}}$ & $8,19^{\mathrm{b}}$ & $8,19^{\mathrm{b}}$ & 8,41 \\
\hline
\end{tabular}

The highest average water content was 8.90 in F2H1 treatment (ginta bioactivator and 6 days fermentation time) and the lowest was 7.82 in $\mathrm{F} 3 \mathrm{H} 2$ treatment (starbio + ginta bioactivator and 10 days fermentation duration). The results showed that the starbio bioactivator water content and fermentation duration of 6 days was higher than the water content of starbio + gourd bioactivator. This is related to Suparmo's (1989) statement, which states that water is one of the by-products of the fermentation process which will affect the water content of the fermented product substrate. Increased water content due to microorgnism begins to utilize carbohydrates that are easily fermented in the substrate as a source of energy to grow and develop.

\subsection{Crude protein}

Protein content of a feed ingredient in general can be calculated by analysis of crude protein content. Protein content analysis is an attempt to determine the protein content of feed ingredients.

\begin{tabular}{lcccc}
\hline \multirow{2}{*}{ Bioactivator } & \multicolumn{3}{c}{ Fermentation Length (days) } & \multirow{2}{*}{ Average } \\
\cline { 2 - 4 } & \multicolumn{2}{c}{ H1 (6) H2 (10) } & H3 (14) & \\
\hline F1 ( Starbio ) & $10,4^{\mathrm{c}}$ & $11,20^{\mathrm{b}}$ & $12,27^{\mathrm{a}}$ & $11,29^{\mathrm{b}}$ \\
F2 ( Ginta ) & $6,37^{\mathrm{h}}$ & $6,91^{\mathrm{g}}$ & $7,44^{\mathrm{e}}$ & $6,96^{\mathrm{a}}$ \\
F3 (Starbio + Ginta) & $6,47^{\mathrm{h}}$ & $7,17^{\mathrm{f}}$ & $8,48^{\mathrm{d}}$ & $7,37^{\mathrm{a}}$ \\
\hline Average & $7,75^{\mathrm{a}}$ & $8,42^{\mathrm{b}}$ & $9,40^{\mathrm{c}}$ & 8,38 \\
\hline
\end{tabular}

On 14 days fermentation, the increase in crude protein content became $12.27 \%$. This crude protein increase shows the occurrence of proteolytic bacteria proliferation. The greatest activity of proteolytic bacteria was at 14 days fermentation time, which was $12.27 \%$. This is in accordance with the statement of Agustono et al. (2010) during the fermentation process increased crude protein content caused by an increase in the number of microbial biomass. Fungi that have the ability to produce protease enzymes will remodel proteins. Protein is transformed into a polypeptide, then it becomes a simple peptide which eventually undergoes further alteration into amino acids, which will be utilized by microbes to multiply. Increasing the number of microbial colonies which are single cell proteins during the fermentation process indirectly increases the crude protein content of the substrate.

\subsection{Rough Fat}

\begin{tabular}{lcccc}
\hline \multirow{2}{*}{ Bioactivator } & \multicolumn{3}{c}{ Fermentation Length (days) } & \multirow{2}{*}{ Average } \\
\cline { 2 - 4 } & \multicolumn{2}{c}{$\mathrm{H} 1(6) \mathrm{H} 2(10)$} & $\mathrm{H} 3(14)$ & $1,22^{\text {tn }}$ \\
\hline F1 ( Starbio ) & 1,24 & 1,20 & 1,22 & $1,23^{\text {tn }}$ \\
F2 ( Ginta ) & 1,27 & 1,21 & 1,21 & $1,24^{\text {th }}$ \\
F3 (Starbio+Ginta) & 1,22 & 1,25 & 1,25 & 1,23 \\
\hline Average & $1,24^{\mathrm{tn}}$ & $1,22^{\mathrm{tI}}$ & $1,22^{\mathrm{tl}}$ & \\
\hline
\end{tabular}

The highest average of 1.27 was found in F2H1 treatment (ginta bioactivator and 6 days fermentation time) and the lowest average was 1.20 in $\mathrm{F} 1 \mathrm{H} 2$ treatment (starbio bioactivator with 10 days fermentation duration). This is consistent with Kusnandar's statement (2010), which states that fat is a nonpolar ester compound which is insoluble in water, which is produced by plants and animals. The fat produced from plants is called vegetable fat, whereas from animals it is called animal fat. Fats and oils are 
mainly composed of carbon atoms $(\mathrm{C})$, hydrogen $(\mathrm{H})$, and oxygen $(\mathrm{O})$, but contain more hydrogen and less oxygen than carbohydrates.

\subsection{Coarse Fiber}

Coarse fiber is a residue from food or agricultural products after being treated with acid or boiling alkali, and consists of cellulose, with little lignin and pentose.

\begin{tabular}{llcll}
\hline \multirow{2}{*}{ Bioactivator } & \multicolumn{2}{c}{ Fermentation Length (days) } & \multirow{2}{*}{ Average } \\
\cline { 2 - 4 } & \multicolumn{2}{c}{$\mathrm{H} 1(6) \mathrm{H} 2(10)$} & $\mathrm{H} 3(14)$ & \\
\hline F1 ( Starbio ) & $8,82^{\mathrm{c}}$ & $8,52^{\mathrm{e}}$ & $8,11^{\mathrm{f}}$ & $8,48^{\mathrm{d}}$ \\
F2 ( Ginta ) & $9,78^{\mathrm{a}}$ & $9,24^{\mathrm{b}}$ & $8,35^{\mathrm{e}}$ & $9,12^{\mathrm{a}}$ \\
F3 (Starbio + Ginta) & $8,64^{\mathrm{d}}$ & $8,48^{\mathrm{e}}$ & $8,41^{\mathrm{e}}$ & $8,51^{\mathrm{d}}$ \\
\hline Average & $9,08^{\mathrm{a}}$ & $8,74^{\mathrm{b}}$ & $8,29^{\mathrm{b}}$ & 8,78 \\
\hline
\end{tabular}

The highest average of crude fiber was 9.78 in F2H1 treatment (ginta bioactivator and 6 days fermentation time) and the lowest was 8.11 in F1H3 treatment (bio-activator satrbio and fermentation duration 14 days). This fermented coarse fiber is lower if the fermentation time is $\mathrm{H} 3$ compared to H1. This shows that the crude fiber of cassava skin has decreased. The average content of crude fiber of cassava skin using starbio and local microorganisms (Ginta) and fermentation time is 6.10 and 14 days. This is in accordance with Elius's (2017) statement, which states that the fermentation process is carried out by adding a local microorganism (MOL) "Ginta" stater that matches the substrate and is in accordance with the fermentation process. The formation of "ginta" local microorganism mold (MOL) as stater in the fermentation process is considered to be the most suitable and suitable for the purpose of fermentation, namely by reducing the level of crude fiber and at the same time increasing crude protein content.

\subsection{Ash Content}

Ash content has something to do with mineral feed ingredients. The process for determining the amount of residual combustion minerals is called ignition. To determine the ash content of feed ingredients using a furnace. Furnace heat reaches 6000C. The content and composition of ash or minerals in the ingredients depends on the type of feed ingredients. Ash is an inorganic substance remaining from the combustion of an organic material. The ash content of a material shows the mineral content in the feed ingredients.

\begin{tabular}{|c|c|c|c|c|}
\hline \multirow[t]{2}{*}{ Bioactivator } & \multicolumn{3}{|c|}{ Fermentation Length (days) } & \multirow[t]{2}{*}{ Average } \\
\hline & H1 (6) & $\mathrm{H} 2(10)$ & H3 (14) & \\
\hline F1 ( Starbio ) & 5,36 & 5,42 & 5,35 & $5,37^{\mathrm{tn}}$ \\
\hline F2 ( Ginta ) & 5,36 & 5,38 & 5,33 & $5,35^{\mathrm{tn}}$ \\
\hline F3 (Starbio + Ginta) & 5,26 & 5,58 & 5,65 & $5,50^{\mathrm{tn}}$ \\
\hline Average & $5,32^{\mathrm{tII}}$ & $5,46^{\mathrm{tm}}$ & $5,44^{\text {tII }}$ & 5,40 \\
\hline
\end{tabular}

The highest average ash content was 5.65 in $\mathrm{F} 3 \mathrm{H} 3$ treatment (bioactivator starbio and ginta with 14 days fermentation time) and the lowest was 5.26 in $\mathrm{F} 3 \mathrm{H} 1$ treatment (starbio and ginta bioactivators with fermentation duration of 6 days). Ash content dropped back to F2 treatment to 5.35\%. This happens due to an increase in organic matter with the degradation process of materials (substrates) by microorganisms. Then the ash content increased again in F3 treatment, where the ash content of F2 and F1 showed an unreal difference. Styawati et al. (2013) stated that the less organic matter is degraded, the less the proportion of ash content will be proportionally decreased, whereas the more organic matter is degraded, the more proportional the increase in ash content will be.

\subsection{BETN}

The BETN content of a feed ingredient is highly dependent on other components, such as water, ash, crude protein, crude fiber and crude fat. If the amount of water, ash, crude protein, crude fat and crude fiber is reduced from 100, the difference is called extract material without nitrogen (BETN). 
Decrease in BETN levels seen from the nutritional aspect is less profitable, because the less BETN, the less organic components can be digested so that less energy can be produced (Sutardi, 2006).

\begin{tabular}{lcccc}
\hline Bioactivator & \multicolumn{3}{c}{ Fermentation Length (days) } & \multirow{2}{*}{ Average } \\
\cline { 2 - 4 } & $\mathrm{H} 1(6)$ & H2 $(10)$ & H3 $(14)$ & \\
\hline F1 ( Starbio ) & $74,17^{\mathrm{d}}$ & $73,64^{\mathrm{e}}$ & $73,01^{\mathrm{e}}$ & $73,60^{\mathrm{b}}$ \\
F2 ( Ginta ) & $77,2^{\mathrm{b}}$ & $77,24^{\mathrm{b}}$ & $78,65^{\mathrm{a}}$ & $77,70^{\mathrm{a}}$ \\
F3 (Starbio + Ginta) & $77,39^{\mathrm{b}}$ & $77,51^{\mathrm{b}}$ & $76,20^{\mathrm{c}}$ & $77,03^{\mathrm{a}}$ \\
\hline Average & $76,25^{\mathrm{a}}$ & $76,13^{\mathrm{a}}$ & $75,95^{\mathrm{b}}$ & 76,11 \\
\hline
\end{tabular}

The highest average of BETN is 78.65 in F2H3 treatment (demand bioactivator and 14 days fermentation time) and the lowest is 77.2 in $\mathrm{F} 2 \mathrm{H} 1$ treatment (local microorganism biactivator "ginta" with 6 days fermentation time).

\section{Conclusion}

1. Fermentation using starbio can increase crude protein, BETN, and reduce coarse fiber, moisture content, and ash content.

2. 14-day fermentation has the effect of increasing crude protein, BETN, and reducing ash content, crude fiber, crude fat, moisture content.

3. The use of starbio and local microorganisms "ginta" with 14 days of fermentation can increase the crude protein of cassava skin.

Suggestion

To improve the nutritive value of cassava tuber skin should use starbio with fermentation time of 14 days.

\section{References}

[1] Agustono, A.S., Widodo dan W. Paramita. 2010. Kandungan Protein Kasar dan Serat Kasar pada Daun Kangkung Air (Ipomoea Aquatica) Yang Difermentasi. Jurnal Ilmiah Perikanan dan Kelautan Vol. 2, No. 1, Hal 37-43.

[2] Kusnandar F, DR. Adawiyah, M Fitria, 2010. Pendugaan umur simpan produk biskuit dengan metode akselerasi berdasarkan pendekatan kadar air kritis. Jurnal Teknologi dan Industri Pangan 21(2): $117-122$.

[3] Sutardi,T .2006 . Landasan Ilmu Nutrisi Jilid I .Departemen Ilmu Makanan Ternak .Bogor :Fakultas Peternakan IPB.

[4] Styawati, N.E., Muhtarudin, dan Liman. 2013. Pengaruh Lama Fermentasi Trametes sp. Terhadap Kadar Bahan Kering, Kadar Abu, dan Kadar Serat Kasar Daun Nenas Varietas Smooth Cayene. Fakultas Pertanian Universitas Lampung

[5] Supriadi. 1995. Pengaruh Tingkat Penggunaan Hasil Fermentasi Kulit Ubi Kayu oleh JamurAsfergillus nigerdalam Ransum terhadap Performan Ayam Pedaging Periode Starter. Skripsi. Universitas Padjadjaran, Bandung. 